Published in Proceedings of the Geologists' Association, 2012, Volume 123, 520-532

Note that this version of the text does not include the Journal's editorial and proof corrections

\title{
The pedigree and influence of fossil collections from the Falkland Islands: from Charles Darwin to Continental Drift
}

\author{
P. Stone ${ }^{1}$ \& A. W. A. Rushton ${ }^{2}$ \\ 1. British Geological Survey, Murchison House, West Mains Road, \\ Edinburgh EH9 3LA, UK. \\ 2. Department of Palaeontology, The Natural History Museum, Cromwell Road, \\ London SW7 5BD, UK.
}

\begin{abstract}
The Falkland Islands are typical of remote territories in that their early geological exploration was piecemeal and opportunistic. Whilst the resulting fossil collections (dominantly a Devonian fauna of the Malvinokaffric realm) remain the basis for modern interpretations, published accounts misrepresent their extent and provenance. Charles Darwin first discovered fossils during his 1833 visit aboard HMS Beagle, with subsequent British collections acquired in 1842 and 1876 respectively by the Erebus \& Terror and Challenger expeditions and in 1903 by the Scotia expedition. Darwin's collection, and much of the other material, is now held by The Natural History Museum, London (NHM) but some Darwin specimens were assimilated into other collections whilst at least one NHM 'Darwin' specimen was not collected by him. There may also be some uncertainty as to the origin of the Scotia collection, now held in Edinburgh by National Museums Scotland, in relation to a contemporary Swedish collection now held in Stockholm. The NHM holdings were supplemented by a number of enigmatic donations from private individuals and then by fossils collected during the first 'official' geological survey of the islands in 1920-1922. Meanwhile a large collection was built up in New York through collaboration in 1909 with a local collector - the Governor's wife! The regional associations of the fossils
\end{abstract}


established the African heritage of Falklands geology, and thereby contributed to an understanding of continental drift as the mechanism for the fragmentation of the Gondwana supercontinent. The Falkland Islands are now regarded as a rotated microplate created during the break-up.

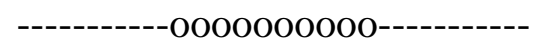

The Falkland Islands lie in the South Atlantic Ocean around $52^{\circ}$ south, $60^{\circ}$ west. The archipelago is made up of two main components, East and West Falkland, a dozen or so large subsidiary islands, and myriad smaller islands, rocks and reefs (Figure 1). These all add up to a total land area of just over $12000 \mathrm{~km}^{2}$. A comprehensive account of the geology is given by Aldiss \& Edwards (1999). The oldest rocks seen are the Proterozoic, ca 1000 million years old, granite and gneiss of the Cape Meredith Complex, which has a very small outcrop on the southernmost point of West Falkland. This 'basement' complex is unconformably overlain by the West Falkland Group, a thick succession of marine, near-shore clastic strata that is unequivocally Devonian in part but which may range in age from Silurian to Carboniferous. A younger division, the Lafonia Group, has a Permo-Carboniferous glaciogenic unit near its base and passes upwards into a thick succession of Permian lacustrine strata. The metamorphic and sedimentary rocks are cut by a multitude of Jurassic and Cretaceous dolerite dykes.

The early history of geological research in the Falkland Islands is largely one of opportunistic study and specimen collection during the course of expeditions whose primary focus was elsewhere. Two visits were made during the archetypal exploration and survey voyage of HMS Beagle, 1831-1836, which brought the young Charles Darwin to East Falkland in 1833 and again in 1834. Well-documented, subsequent visits were made during the Antarctic exploration voyage of HMS Erebus and HMS Terror in 1839-1843, the oceanographic survey voyage of HMS Challenger in 18721876, and by the Scottish National Antarctic Expedition aboard the Scotia in 19021904.

All of these expeditions returned to Britain with fossil collections - mostly brachiopods but also crinoids and fragments of trilobites - in sandstones that in terms 
of modern stratigraphical nomenclature are assigned to the Fox Bay Formation (West Falkland Group, Figure 1) and are now known to be of Devonian age, about 400 million years old. The fossils in these early collections are impressions (natural moulds) of the original animals, their shell material having been dissolved away, preserved in yellow-brown, micaceous sandstone and dark grey mudstone. The Beagle, Challenger and Scotia collections were described in the contemporary scientific literature. The Beagle, Erebus \& Terror and Scotia collections survive in British museums, the first two in the Natural History Museum, London, the third in the National Museums Scotland, Edinburgh. In addition to these documented, expedition collections, there are in the Natural History Museum London, various other fossil specimens from the Falkland Islands donated during the second half of the $19^{\text {th }}$ Century by a range of individuals most of whom had no known connection to the islands. The provenance of other early $20^{\text {th }}$ Century donations tends to be better established, whilst well-documented collections from that period are also now held in Stockholm and New York.

In this paper we consider the circumstances surrounding the principal collections of fossils from the Falkland Islands, and establish hitherto unsuspected links between some of them. Where possible, we provide additional background information for some of the less well-known donated specimens. The reliability of documented provenance is assessed, and disputed in some cases, so that the overall pedigree of the extant collections can be assessed. This is of historical importance as these fossils were influential in the early $20^{\text {th }}$ Century debate surrounding the concept of continental drift, as will be shown.

\section{Charles Darwin and the Beagle}

The second surveying voyage of HMS Beagle, commanded by Robert Fitzroy, is a well-documented, seminal event in scientific history; palaeontology in the Falkland Islands began during that voyage when, in March 1833, Darwin discovered fossil shells at Port Louis, Berkeley Sound (Figure 1). In many ways, it is surprising that he was able to make the first discovery since even in 1833 the Falkland Islands were not exactly terra incognita. The first attempt to settle in the previously uninhabited archipelago was made by French colonists led by Antoine Louis de Bougainville, who 
in 1764, established Port Louis and named it after the French king of the time; the island group was known to the French as Les Malouines, so-called after the expedition's home port of St Malo. Subsequent Spanish-speaking settlers adopted and modified the name to Las Malvinas. Accompanying Bougainville’s expedition was a naturalist-priest, Dom (perhaps an abbreviation of Dominie) Pernety, who published a description of the islands in 1770, with an English translation published a year later (Pernety 1771). Then, early in the $19^{\text {th }}$ Century as the sealing and whaling industries became established, the Falkland Islands were much frequented, with some of the more erudite captains writing accounts of the wildlife and geography (e.g. Weddell 1825). Today, fossils are readily found on many of the beaches and in the coastal outcrops around Berkeley Sound and elsewhere, but it seems that they went unnoticed - or at least unremarked - by the early vistors. Darwin had with him a copy of Pernety's book, which describes geological structures and landforms but makes no mention of fossils. In his diary, Darwin comments on Weddell's observations around Tierra del Fuego so was clearly aware of Weddell's work, and whilst at Port Louis in 1833 he met with and quizzed Matthew Brisbane, Weddell's erstwhile lieutenant; fossils do not seem to have featured in their conversation. For this and subsequent references to Darwin’s ‘Beagle’ diary we have used the version edited by Keynes (1988).

The fossil specimens recovered from the Falkland Islands by Darwin are now housed mostly in The Natural History Museum, London, with a few in the Sedgwick Museum, Cambridge, and are regarded as national treasures (Figure 2). As will be explained later, there may be more of them in the first of these collections than is currently appreciated. The importance of the fossils to the general development of Darwin's ideas has been discussed by several of his biographers (e.g. Armstrong, 1992; Herbert, 2005) and they have been illustrated as part of modern geological accounts (Stone, Aldiss \& Edwards, 2005).

Darwin's excitement at his fossil discovery can be judged from his diary entry for 17 March 1833 ... "The whole aspect of the Falkland Islands were however changed to my eyes ... for I found a rock abounding with shells; \& these of the most interesting geological æra”. Why the most interesting era? Darwin would have seen similar rocks and fossils on his Welsh excursion with Adam Sedgwick prior to departing on the 
Beagle, and now considered his Falklands fossils to be, like the Welsh examples, from strata of the oldest age likely to contain organic remains. This was interesting in itself in such a remote location, but he was also enthused by the possibility of comparing ancient faunas from different parts of the Globe. These aspects of Darwin's developing scientific philosophy have been more fully assessed by Armstrong (1992) and Herbert (2005). In the Falklands, Darwin noted that his fossil collection consisted only of impressions of the original animal shells, and speculated on what might have become of those shells and their $\mathrm{CaCO}_{3}$. In other geological studies he accurately noted and described aspects of the Falklands structure, and puzzled over the origin of the 'stone runs', huge periglacial blockfields that locally dominate the Falklands landscape and are particularly well developed on the south side of Berkeley Sound (the best solution he could devise was based on earthquakes but he knew that it was unsatisfactory).

On his return to Britain, Darwin's fossils were identified and formally described in a scientific paper published by the Geological Society of London (Morris \& Sharpe, 1846) for which Darwin wrote an introductory account of Falkland Islands geology (Darwin 1846). John Morris (1810-1886) and Daniel Sharpe (1806-1856) were amongst the pre-eminent palaeontologists of their time and from Darwin's collection they described eight species of brachiopod and recorded the presence of a bivalve, crinoid columnals and fragmentary trilobite remains. Thereafter, the key specimens appear to have passed into the care of the Museum of Practical Geology (MPG), the Geological Survey's museum that had been established in 1841. They moved to their present home at The Natural History Museum in 1881, following the establishment of that institution as a separate branch of the British Museum. At first, the new museum was known as the British Museum (Natural History) and only became an independent entity, and The Natural History Museum, as recently as 1965. However, for simplicity, in this account we will refer to it consistently as The Natural History Museum (NHM) irrespective of any resulting anachronism.

Neither Darwin (1846) nor Morris and Sharpe (1846) refer to specific collecting sites in the Falkland Islands. From Darwin's diary and notebooks it is clear that all of the fossils that he collected personally in the Falkland Islands came from the area around Port Louis, at the head of Berkeley Sound, East Falkland. However, one specimen in 
the NHM's Darwin collection is noteworthy as having been found not at Port Louis but at Burnt Harbour, a location on Saunders Island off the north coast of West Falkland (Figure 1). In his 1846 account Darwin wrote: "My examination was confined to the eastern island; but I have received, through the kindness of Captain Sulivan and Mr. Kent, numerous specimens from the western island, together with copious notes, sufficient to show the almost perfect uniformity of the whole group." Bartholomew Sulivan (later to become Admiral Sir Bartholomew Sulivan) was a lieutenant on HMS Beagle and a particular friend of Darwin; William Kent was the assistant surgeon on board. However, the specimen from Saunders Island has no connection to the Beagle expedition, and was in fact collected by Sulivan more than ten years later, during the 1844-45 austral summer when he was again surveying around the Falkland Islands in command of HMS Philomel. This is made clear in two letters that he wrote to Darwin (Darwin Correspondence Project Database). In the first, dated 13 January to 12 February 1845, Sulivan describes fossils he had found on the south side of Saunders Island - “ They are only casts of shells but are very numerous being 15 in number on one bit of stone about 15 square inches” - and includes a small sketch of an Australocoelia palmata. His account perfectly matches the specimen (Figure 3a) and it was most probably Sulivan who scratched the

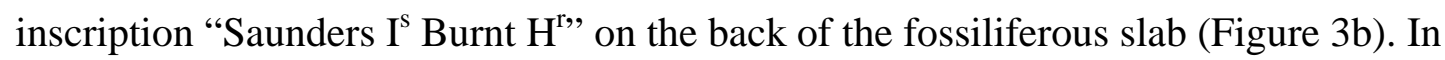
the second letter, written from Montevideo and dated 4 July 1845, Sulivan tells Darwin that he is sending a box containing South American fossils but including those “... from Saunders Island near Port Egmont further to the Westward than any I had before found.” The specimen would have arrived just in time to be included in Morris and Sharpe's description of the Falkland Islands fossils, which was presented at a meeting of the Geological Society of London on 25 March 1846.

A small number of fossil specimens from Darwin's Falkland Islands collection are now held by the Sedgwick Museum, Cambridge. These were retained by Darwin during his lifetime and then, along with most of his rock specimens, they were donated to Cambridge University by his second son, George, in 1897, fifteen years after Charles’ death (Anderson, 2009). The Sedgwick Museum fossil specimens are less imposing than most of those in the NHM collection, and were probably the examples not selected for close examination by Morris and Sharpe. 


\section{Robert Etheridge (senior) and Daniel Sharpe}

Surprisingly, when they arrived in 1881, Darwin's Falklands fossils were not the first specimens from those remote islands to come into the NHM's collection. In 1869 Robert Etheridge had sold to the NHM a large collection of fossils, mostly comprising British material from the Bristol area (Woodward 1904) but apparently including two specimens of Falkland Islands brachiopods, the larger of which is particularly striking (Figure 4). There is no extant record of how he had acquired them. The Falklands specimens are not mentioned in the manuscript list provided by Etheridge to accompany the sale, and preserved in the NHM library. One carries the number 2 in black ink, the other carries a small, white, paper rectangle inscribed $\mathrm{N}^{\mathrm{o}} \mathrm{VI}$, and is also marked with the number 6 in black ink; in Etheridge's manuscript list the numbers 2 and 6 are assigned to British fossils. Perhaps the Falklands specimens are the survivors of an additional small group of foreign material that was passed on as a complement to the British collection. That may explain the NHM catalogue entry that describes Etheridge's Falkland Islands fossils as having been presented rather than purchased. As donations, they may have been treated more casually than the purchased specimens since there was no expenditure of public money to be accounted for.

Etheridge's two specimens are similar in size, fauna, preservation and host lithology to those recovered by Darwin from Port Louis and so may well be additional material from that locality. One telling feature in this respect is the very slight tectonic deformation of the fossils, a feature that is characteristic of the Port Louis area of East Falkland but which is not seen elsewhere in the archipelago. At the time of the sale, Etheridge was Palaeontologist to HM Geological Survey and was based at the Museum of Practical Geology (MPG), where he would almost certainly have encountered Darwin’s specimens since his duties had included curation and cataloguing. Is it possible that two of Darwin's specimens found their way into Etheridge's personal collection and were then passed on to the NHM? Curiously, Etheridge eventually followed his fossils to the NHM in 1881, accompanying the transfer there of the foreign material, including Darwin's specimens, from the MPG. Though perhaps unlikely, it is just possible that the Falklands fossils presented by Etheridge might properly be considered part of the NHM's Darwin collection. Against 
that interpretation are the specimens' surviving labels as noted above. The numbering in black ink is described by Woodward (1904) as a feature of the fossils sold by Etheridge, and is distinct from that used by Darwin on his specimens, several of which in the NHM collection still carry pre-printed labels from his red series.

Whatever the provenance of the Etheridge specimens, from documented evidence we have established (Stone and Rushton 2007) that a few of Darwin's Falklands fossils did not catch up with the main collection in the NHM until 1927 - and have been hitherto unrecognised as Darwin material. These specimens formed part of the Sharpe Collection, which had passed to the Geological Society of London in 1856 on the death of Daniel Sharpe (sadly premature, as the result of a riding accident, whilst he was the Society’s serving president). The Geological Society maintained its own museum until 1927, when its collection was distributed; British material went to the MPG with foreign specimens passed to the NHM. The Sharpe collection as received at the NHM contained about a dozen Falkland Islands specimens, some in several parts and all relatively small. Most have the appearance of flakes removed from larger specimens during Sharpe's development of the original material. Their provenance is confirmed by faded, manuscript notes accompanying some of the specimens that acknowledge 'C. Darwin Esq.' (Figure 5). Clearly, Sharpe retained for his personal collection some of Darwin's Falklands material, and it would seem that John Morris did the same since one of the NHM 'Darwin' specimens is marked 'Morris Collection'. However, in Morris's case the 'borrowed' fossil was apparently reunited with the main collection before the 1880 move from the MPG to the NHM.

\section{Robert McCormick and the Erebus \& Terror fossils}

There is some historical irony in a previously unremarked collection of 13 Falkland Islands fossil specimens acquired by the NHM in 1890 as part of the McCormick bequest. This comprised rock specimens collected on Arctic and Antarctic expeditions and about 250 fossils, chiefly brachiopods, from “ ... the Arctic Regions, Madeira, Kerguelan Land, the Falkland Islands and Tasmania”. Robert McCormick had enjoyed a long naval career and had started out as surgeon on HMS Beagle but left the voyage early complaining that Darwin’s presence restricted his own natural history investigations. He subsequently visited the Falklands when acting as surgeon to James 
Clark Ross’s Erebus \& Terror Antarctic expedition., and in 1842 he collected fossils there.

The explorations of HMS Erebus and HMS Terror, under the command of James Clark Ross, had as a principal purpose the investigation of the South Magnetic Pole. The Falkland Islands were visited late in the voyage when the ships over-wintered in Berkeley Sound in 1842. On board the Erebus, as Assistant Surgeon and Naturalist, was the botanist Joseph Hooker who later became one of Victorian Britain's preeminent scientists as Director of the newly established Royal Botanical Gardens at Kew in London - and formed a firm friendship with Charles Darwin. Hooker made an extensive study of the Falkland's plants, whilst the senior surgeon aboard Erebus, Robert McCormick, collected bird specimens and picked up a few fossil brachiopods. After the expedition, McCormick wrote appendices for the official account (Ross, 1847) that described the geology of New Zealand, Tasmania and several of the subAntarctic islands, but added nothing on the geology of the Falklands. He was perhaps mindful of Darwin’s previously published accounts (Darwin, 1839; 1846).

The McCormick fossils came from the shores of Berkeley Sound and 'St Salvador Bay' (now Port Salvador). This extended the geographical range of the fossiliferous strata discovered by Darwin in East Falkland, though that fact has not been noted in subsequent accounts and McCormick’s brachiopods have never been formally described. The fossil specimens themselves (Figure 6) are variably wave-worn and all give the impression of having been picked up as loose blocks from the beach, though some have clearly been carefully trimmed. Most commonly present are Notiochonetes, Schellwienella and Australospirifer, but other brachiopods identified in the Darwin collection are also represented. Several specimens show the impressions of crinoid columnals, and one carries those of tentaculitid shells, a form not recorded by Darwin. We can confirm from recent observations that tentaculitids are relatively rare around Berkley Sound (provenance of Darwin's specimens) but common at some localities in Port Salvador. Had they been noted at the time, this would have been the first record of tentaculitids from the Falklands. Instead, the McCormick collection has no contemporary references and seems to have lain, curated but otherwise un-noticed, for 120 years. 


\section{Benjamin Bright}

One Falkland Island specimen in the NHM collection, donated in 1873 by 'Benj. Bright Esq', is of interest from both the geological and historical point of view. It shows several shells of Australospirifer hawkinsii in a brown sandy matrix but the rock carries a rough anastomosing cleavage and the shells themselves are quite strongly deformed. Slight deformation of the fossils is fairly common in (and mostly restricted to) the Berkeley Sound outcrop of the Fox Bay Formation, but Bright's specimen is the most deformed example known to the authors. Another unusual feature is that some of the original shell material is still preserved; in general, fossils from the Berkeley Sound outcrop are preserved only as impressions, the shell material having been dissolved. The host lithology is a good match for Fox Bay Formation sandstone but some slight uncertainty is introduced into the specimen's provenance by its NHM catalogue reference as 'Falkland Islands?'

The survival of this specimen would seem to have been against the odds. Cleevely (1983) records that in 1870 Benjamin Bright (1823-1900) sold his house but left abandoned inside it a large number of fossils. According to Cleevely the purchaser, Lord Ashburnham, "requested the British Museum to take them away in 1873, when the property was utilised as a source of building materials.” This was done, but much material was unsalvageable, as described by Woodward (1904): "Besides the valuable minerals and the vertebrate remains, there were over 3,000 fossil invertebrates, chiefly British, but from having been left in rooms exposed to damp, mice and nesting birds, all manuscripts and labels had perished.” It was a sad end for a family fossil collection begun by Benjamin’s grandfather, Richard Bright, and continued by his father, also Benjamin. The younger Benjamin would seem to have had little interest in his inherited fossils, so the Falkland Islands specimen was probably acquired either by Richard (1754-1840) or Benjamin senior (1787-1843). In either case, their active collecting days may well have pre-dated Darwin's 1833 fossil discovery, making the Bright specimen a contender for the accolade of 'first fossil from the Falklands’ As a Bristol-based merchant and banker, Richard would have been well-placed to acquire curios from distant lands. Benjamin senior's main enthusiasm is known to have been for Silurian fossils, which would have made the early Devonian, Falklands brachiopods of interest to him. 


\section{Fossils acquired during the Challenger expedition}

The Challenger expedition, under the leadership of Charles Wyville Thomson, Professor of Natural History at Edinburgh University, was a revolutionary cruise of oceanographic survey and sampling. The Falkland Islands were visited late in the voyage, in January 1876. There, at the request of the Governor, Colonel D’Arcy, expedition scientists went from Stanley across to Port Sussex on the west coast of East Falkland to check on a reported occurrence of coal. This proved unfounded but as Thomson (1877) described it “... Mr Moseley brought back a fine lot of fossils from the sandstone ...”. Remarkably, Moseley also carried home, on horseback, the skeleton of a small whale!

The provenance of the fossils recovered is not absolutely clear. Thomson's account implies that they were brought back from Port Sussex, but the fossiliferous Fox Bay Formation sandstones - the source of the fossils - do not crop out there. The fossils were described in the scientific report of the voyage by Robert Etheridge Junior, son of the NHM's earlier benefactor and confusingly sharing his name. Etheridge Jnr (1885) states that the Challenger fossils were brought from Port Louis, but it seems most unlikely that Moseley would have travelled from Stanley to Port Sussex via a lengthy detour to Port Louis although, depending on his route, he could have crossed outcrop of the Fox Bay formation at the south-east end of Port Salvador (Figure 1). Thomson notes that later “... we went round to the head of Berkeley Sound, and saw the old station of St. Louis (sic) ...”, but no mention is made of fossils in that context. One other peculiarity is the reference by Etheridge to a fossil specimen from Macbride's (now Macbride) Head, on the north coast of East Falkland, which is remote from any known outcrop of the Fox Bay Formation and does not seem to have been visited by expedition personnel. Perhaps the fossil specimens were simply presented to Moseley by a local benefactor.

In his description of the fossils, Etheridge (1885) noted that, of the Challenger brachiopods, Orthis (now Schellwienella) sulivani was by far the most common - “... present on almost every block of sandstone ...”. Australospirifer was also well represented, whilst Australocoelia in large number were “... scattered about the 
fossiliferous layers of the blocks from Port Louis, and the mass from Macbride's Head ...”. As mentioned above, the latter specimen is almost certainly mis-located. Etheridge also described the broken internal mould of a marine gastropod, the first fossil record of such a taxon from the Falklands. No illustrations accompanied Etheridge's account and sadly we have been unable to locate the collection that he described, either in The Natural History Museum or elsewhere.

\section{Hermann Henry Hoffert}

H H Hoffert (1860-1920) was Demonstrator of Physics at the Royal School of Mines from 1876 until 1881 and then became Professor of Experimental Physics at the University of London. His interest in natural history and geology is confirmed by two volumes of mammal and bird sketches dating from 1876-77 and now held by the Wellcome Library, London; inserted loose in the first volume are two coloured charts illustrating English rocks. In 1891 Hoffert donated four specimens from the Falkland Islands to the NHM collection, three brachiopods and a trilobite. There is no evidence to show how or where he acquired the specimens, which are of relatively poor quality. The preservation character, particularly of the trilobite, is dissimilar to that of the material from Port Louis and his fossils may have originated in West Falkland. Hoffert's contribution is of most interest for an enigmatic entry in Cleevely (1983) that notes, under his name and allegedly held by the NHM, 'Palaeozoic Pisces from the Falkland Islands, 1891'. No such fish collection can be found, and indeed fish remains are extremely rare in the West Falkland Group (Maisey et al. 2002) and have not been reported from the Lafonia Group despite the presence there of the fishinduced trace fossil Undichna (Trewin 2000). The date, 1891, coincides with the date of presentation for the brachiopods and trilobite so it seems likely that in this instance Cleevely was in error.

\section{The Bruce collection from the Scotia expedition}

The Scottish National Antarctic Expedition sailed from the Clyde in November 1902 aboard the Scotia. The Falklands were reached in January 1903 and three weeks were spent taking on additional supplies. During that time Governor (later Sir) William Grey-Wilson entertained the expedition's scientists, and is reported to have presented 
their leader, William Speirs Bruce, with a collection of fossils from the Fox Bay Formation sandstone at Port Louis. These were mostly brachiopods but included two small fragments of a trilobite. Bruce was also given one other specimen of sandstone with fossil impressions from the far west of the Falklands archipelago. The donor was Mr W. Felton of West Point Island who claimed to have found the fossils, crinoids in this case, on the nearby mainland at Hope Point (Figure 1) although the Fox Bay Formation is not seen in that vicinity. The Scotia fossils were described by Edwin Newton (1906).

The specimens themselves (The Bruce Collection, National Museums of Scotland) are mostly rather worn and the rock slabs in which they are preserved were probably collected as loose blocks from the beaches at Port Louis and Hope Point. From Port Louis, the bulk of the collection comprises brachiopods, with Australospirifer particularly well represented; most of the illustrations accompanying Newton's paper were of this variety. There are also several nice examples of Australocoelia (Figure 7), whilst the Scotia collection added one brachiopod taxon - Pleurothyrella? - that had apparently not been recorded previously. A scattering of crinoid fragments is present in many of the samples and, as in the Beagle and Challenger collections, fragments of trilobites are also present. Casts of crinoid fragments are the only fossils seen in the rock slab from Hope Point and from their evidence alone Newton did not feel justified in claiming an unequivocal correlation with the strata at Port Louis. However, the yellow-brown, micaceous sandstone in which they are preserved is a close match for typical Fox Bay Formation sandstone.

In preparing his account, Newton examined Darwin's fossils at The Natural History Museum in South Kensington, London. He makes no mention of having seen the Challenger fossils, now missing, relying on Etheridge's un-illustrated account for his comparison. Nor does he mention McCormick's collection, which had not been described elsewhere, although those specimens were also held by the NHM at the time of his visit.

\section{The Swedish Contribution}


During 1902, only a few months ahead of the Scotia expedition, the geologist J. Gunnar Andersson spent time in the Falklands whilst waiting to rendezvous with the ship (the Antarctic) supporting the 1901-1903 Swedish South Polar Expedition. He made several significant palaeontological discoveries, particularly in West Falkland where he collected fossils at the eponymous Fox Bay. Many of his specimens were subsequently lost when the Antarctic was crushed in pack ice and sank, forcing Andersson and his companions to over-winter in the Antarctic under very difficult circumstances (Nordenskjöld \& Andersson, 1905). They were rescued and returned to the Falklands late in 1903, where Andersson must have relished the prospect of recovering his few remaining Falklands specimens, which had been left stored in Stanley. Sadly his misfortune continued and he later wrote (Andersson 1907) of his disappointment to discover that “... some cases with collections from Port Louis, which had been deposited in Port Stanley, were broken up during our prolonged absence in the South and many of the specimens were carried away.” It may be no more than coincidence that the Scottish expedition had passed through Stanley, and acquired a pre-existing collection of fossils from Port Louis, whilst the Swedes were marooned. Equally, it must be at least possible that the fossils missing from Andersson's collection are now in Edinburgh as part of the Bruce Collection held by National Museums Scotland.

Perhaps surprisingly, Andersson did not despair of the Falkland Islands and arranged for one of his students, Thore Halle, to continue geological investigations there during the course of the Swedish Magellanic Expedition, 1907-1909. Halle made considerable progress towards an overall understanding and his report (Halle, 1912) included a geological map that for the first time defined the distribution of the main rock units across the entire archipelago. The Falkland Island specimens collected by Halle are held by the Natur Historiska Riksmuseet in Stockholm, Sweden, as are the relicts of Andersson's ill-fated collection, the survivors from which are mostly brachiopods from Fox Bay. As an important addition to the Devonian fauna, Andersson had discovered a Permian, Glossopteris-type flora in the Lafonia Group, and Halle accumulated a sizeable collection.

\section{Constance Allardyce and the development of the New York collections}


As an adjunct to his account of Falklands geology, Thore Halle acknowledged the assistance he had received from Mrs Constance Allardyce, the wife of William Lamond Allardyce who had been appointed governor of the Falklands in 1904. Mrs Allardyce had been instrumental in setting up a local museum in Stanley and had stimulated much interest in natural history amongst the islands' farming community. One important result of this was the discovery, probably late in 1908 and shortly after Halle left the islands, of a new fossiliferous locality on Pebble Island, West Falkand (Figure 1). There, the Fox Bay Formation contained mudstone units interbedded with the more characteristic sandstone and, within the mudstone, fossils were preserved in carbonate-rich concretions. The preservation of the fossils was remarkable. In contrast to the natural internal and external moulds seen elsewhere, the Pebble Island concretions preserved the animal shells in every tiny detail (Figure 8). The faunal range was equally impressive: brachiopods, trilobites, snails, bivalves, crinoids and orthocones were all present in abundance.

It was at this timely moment that Governor Allardyce received an enquiry as to the availability of Falkland Islands fossil specimens from John Clarke, an eminent American palaeontologist based at the New York State Museum in Albany, NY. Clarke had been involved in a major review of Devonian fossils from South America, mostly from Brazil and Bolivia, and was seeking to complete the survey by including examples from the Falkland Islands. Mrs Allardyce took on the correspondence and sent Clarke a wealth of Falklands material, including many specimens from the newly discovered Pebble Island locality. Clarke would have been delighted by his good fortune. In return, he was fulsome in his praise for Mrs Allardyce's contribution (Stone, 2009). He named a species of trilobite after her (Metacrypheus allardyceae) and a species of marine snail after her husband, the Governor (Diaphorostoma allardycei); upon her sadly premature death in 1919 (in the Bahamas) he published a glowing obituary in Science (Clarke 1919). But perhaps the greatest tribute came privately, in a letter Clarke wrote to Mrs Allardyce dated 8 January 1910 and reproduced in the Falkland Islands Magazine and Church Paper for May 1910. The letter ends: "I salute you, Mrs Allardyce, as the most successful of Falkland Islands geologists, not excepting Charles Darwin himself.” High praise indeed. Clarke’s account of the Falkland Island Devonian fossils was included with his work on the South American fauna and published as a monograph by the Brazilian Geological 
Survey (Clarke 1913a). Wrongly anticipating publication delays in Brazil, he also published illustrations of the Falkland Islands fossils in the New York State Museum Bulletin (Clarke, 1913b).

For his 1913 accounts of Falklands Devonian palaeontology, in addition to the specimens provided by Constance Allardyce, Clarke had examined the Swedish collections from the Falklands but seems not to have seen any of the material held in British museums, though in his monograph he does make passing reference to Darwin and Newton. Nevertheless, in respect of Falkland Islands geology, Clarke (1913a) has become the standard palaeontological reference, which rather by-passes Darwin's work and that of the other $19^{\text {th }}$ century British expeditions. Moreover, the presence in New York of the well-documented Allardyce-Clarke collection has stimulated further research in more recent times, firstly on the extant material (e.g. Edgecombe, 1994) and then on additional material recovered during a collecting expedition organized from the American Museum of Natural History, New York, in 2000 (e.g. Maisey et al., 2002; Carvalho, 2006).

It is perhaps surprising that Constance Allardyce did not dispatch any of her splendid, Devonian fossils from Pebble Island back to Britain, especially as in 1909 a sample of 'fossil wood' from West Point Island was sent back to the NHM, London, nominally by her husband, the Governor (Figure 9). The wood was originally thought to be of Quaternary age, but is now considered more likely to be Miocene (Macphail \& Cantrill, 2006). Perhaps at the time it was thought of economic interest in terms of the potential for re-forestry of the treeless Falklands. However, not long after the discovery of the Pebble Island fossils, several brachiopod and trilobite specimens from that locality did arrive in the NHM as a donation in 1910 by Arthur Cobb. He was a farm manger in the Falklands (though not of the Pebble Island property) and a noted local ornithologist; for a brief biography see Tatham (2008).

\section{Early-20 ${ }^{\text {th }}$ century mineral prospecting and geological survey}

The first exploration of the Falkland Islands for minerals of economic importance was carried out during the 1913-1914 austral summer by David Ferguson, a geologist employed by the Salvesen Company, operators of a whaling station on New Island, 
West Falkland. Ferguson's visit was relatively brief and his findings were not formally published, though it is clear from his surviving notebooks (held by the Hunterian Museum, University of Glasgow) that he misinterpreted some important aspects of Falklands geology. In fairness, he was misled in one crucial instance by the erroneous report of fossils from Port Sussex that had arisen after the Challenger Expedition. Ferguson's specimen collection survives in the Hunterian Museum and includes several examples of fossils, mostly brachiopods, from outcrops of the Fox Bay Formation in both East and West Falkland. Ferguson's notes also refer to 'corals' but they are not present; it is possible that he was misapplying the name to a conflation of crinoid fragments and tentaculitid impressions, both of which are present in his specimens. The Ferguson collection also contains specimens of wood from the 'buried forest' on West Point Island.

The first Government-sponsored geological survey of the Falkland Islands was carried out between 1920 and 1922 by Herbert Arthur Baker; for a brief biography see Tatham (2008). Like the investigations of Ferguson, Baker's survey was primarily a search for economically important minerals. Though no more successful than Ferguson's in that respect, Baker's work was comprehensive, thorough and enduring; his geological map was not superseded for 50 years, until publication of a photogeological reinterpretation by the British Antarctic Survey (Greenway 1972). Particularly noteworthy was Baker's comparison of the complete Falklands rock assemblage, from the ca 1000 Ma metamorphic Cape Meredith Complex through the Devonian to Permian sedimentary succession and the intrusive dyke swarms, to the comparable geology found in the Cape Province of South Africa. However, despite using facilities at Imperial College, London, when writing-up his survey work, it is not clear whether or not Baker examined the extant fossil collections at the nearby NHM. Instead, the Devonian faunal list included with his final report (Baker 1924) was based on Clarke (1913a), and hence on the Allardyce material in New York and the Swedish collections, rather than the material held in Britain. Baker expanded the list from his own observations, but not all of his additions can be verified from his surviving fossil collection, now divided between The Natural History Museum and Imperial College, London (Stone \& Rushton, 2006); both of these 'sub-collections' contain material from the Pebble Island locality. Baker's donation to the NHM was not made until 1931 but appears to comprise the pick of his specimens (Figure 10), 
most of which are erroneously credited to 'J. Baker' on the museum’s labels. He also collected specimens of the Permian flora which were described by Seward \& Walton (1923); some plant specimens remain at Imperial College but the figured material from the published account is held by the NHM. Regrettably, the collection of rock specimens assembled by Baker in the course of his geological survey has not survived.

\section{Mid-20 ${ }^{\text {th }}$ century donations to the Natural History Museum}

The growth of the NHM's Falkland Islands fossil holding during the mid-20 ${ }^{\text {th }}$ century arose from the collecting efforts of two naturalists based in the Falklands, J E Hamilton and A G Bennett, and the work of a member of the museum's staff, W N Croft. Hamilton and Bennett were both involved in the Falkland Islands Government's supervision of the South Atlantic whaling industry and at various times enjoyed the quasi-official status of 'Government Naturalist'; for brief biographies see Tatham (2008).

James Hamilton first donated material in 1939 with additional fossil specimens being sent by his executors after his death in Stanley in 1957. The bequeathed fossils arrived mixed with a range of other biological specimens: for example, an extant British Museum (Natural History) memorandum accompanying several Australospirifer fossils records that "At the bottom of a box of eggs of Falkland Islands birds were two fossil brachiopods.” Other surviving notes make it clear that specimens had been found by a range of people and then passed on to Hamilton in his role as 'Government Naturalist'. The specimens attributed to Arthur Bennett arrived at the NHM in 1956, after the death of the donor, in England, in 1954. Their provenance is curious in that most, possibly all of them, were collected (or acquired) between 1934 and 1937 by members of the British Graham Land Expedition, with which Bennett had no direct connection, whilst they were in transit to or from the Antarctic. Bennett was, however, much concerned with the development of the Stanley museum, which had been established by Constance Allardyce (see above), and for which, as a self-taught taxidermist, he had preserved and mounted several hundred bird specimens. It seems likely that the expedition members passed their fossils on to Bennett as contributions to the Stanley museum. If so, it was fortuitous that they had not found their way into 
the museum by 1944, when the entire Stanley collection was tragically destroyed in a fire that burnt down the Town Hall, wherein the museum was housed. Expedition members visited Pebble Island and some of the 'Bennett' specimens from that locality are particularly impressive (Figure 11).

William (Bill) Croft joined the NHM as a palaeobotanist in 1939, but in 1940 moved on to war service with the Royal Engineers, rising to the rank of Captain. In 1945-46 he worked with the Falkland Islands Dependencies Survey (forerunner of the British Antarctic Survey) on James Ross and Seymour Islands as described by Fuchs (1982). In transit to and from the Antarctic Croft spent time in the Falkland Islands, travelled widely and collected fossils. He rejoined the NHM in 1947; some of his Falkland Islands specimens were assimilated into the NHM collection then, others were bequeathed after his premature death in 1953, a sad event thought to have been brought forward by his refusal of blood transfusions on religious grounds.

\section{Regional correlations and continental drift}

When describing the Darwin collection, John Morris and Daniel Sharpe (1846) clearly had access to those specimens that ended up in Sharpe's personal collection, and may also have seen the specimens passed to the NHM by Robert Etheridge, particularly if our conjecture as to a Darwinian provenance is correct. It is also likely that Morris and Sharpe were at least aware of the specimens that remained in Darwin's possession until his death, after which they were donated to the Sedgwick Museum. Nonetheless, Morris and Sharpe were cautious in their correlations of the Falklands fauna, suggesting only a general Siluro-Devonian age and drawing only broad comparison with brachiopods previously described from localities in Australia, the Americas and Germany. They concluded “The number of species collected by Mr Darwin from the Falkland Islands is too limited to justify any close comparison with the Palaeozoic fauna of other portions of the globe ... “. This was soon to change.

Several years after the appearance of the Morris and Sharpe account of Darwin's Falkland Islands fossils, Daniel Sharpe, together with John Salter, was called upon to describe an extensive fossil collection from South Africa (Sharpe \& Salter 1856). This 
included a wealth of Devonian brachiopods, trilobites, crinoids, bivalves, snails and tentaculitids from what is now called the Bokkeveld Group (Cape Supergroup). Sharpe and Salter appreciated the association between the South African fauna and that collected in the Falklands by Charles Darwin. In respect of the Bokkeveld Group brachiopods they noted: “... the only locality where any of these South African species have previously been found is in the Falkland Islands; and it is very remarkable that, of the nine (sic) species brought from those islands by Mr Darwin ... five are contained in the collection from the Cape.”

The South African connection was strengthened by the two additional collections of Falklands fossils acquired in 1876 and 1903 respectively by the Challenger and Scotia expeditions. When describing these fossils both Robert Etheridge Junior (1885) and Edwin Newton (1906) referred back to Darwin's discovery, with Newton also mentioning the Challenger collection in the following passage: "On two previous occasions fossils have been brought to this country from the Falkland Islands, namely, by Charles Darwin on the return of the Beagle in the year 1844 (sic) and by the Challenger when she returned from her expedition in 1876.” Newton was clearly unaware of the fossil collection made in 1842 during the Erebus \& Terror expedition although by 1890 the specimens had followed Darwins's fossils into the NHM collection and so should have been available there when he examined Darwin's material. Newton also extended his comparison to the South African fauna, noting: "The specimens ... recorded from the Falkland Islands are so similar to the Brachiopods obtained from the Bokkeveld beds of South Africa, that there can be little doubt as to their being from beds of approximately the same age”.

If any doubt remained about the Falklands - Africa faunal connection, it would have been dispelled by the material supplied by Constance Allardyce to John Clarke in New York, which included a wealth of trilobites. However, in his description of the Falklands specimens, Clarke (1913a) was clearly still taken aback by the Falklands Devonian fauna showing a closer resemblance to that of South Africa, than to that of South America, which he also described in detail, mostly from Brazil and Bolivia. Clarke wrote (1913, pp 56-57): “It is perhaps somewhat extraordinary that in both sedimentary facies and in fauna the resemblance of the Falkland Islands Devonian is closer to that of South Africa than to that of South America”. This entire trans- 
Atlantic fauna is now taken as part of a Malvinokaffric Province, a concept introduced by Rudolf and Emma Richter (1942), and its distribution was crucial to the first attempts to reconstruct a Gondwana supercontinent. Of even greater importance to those reconstructions was the presence throughout Gondwana, including the Falkland Islands, of the Permian Glossopteris fauna.

It was in 1915 that Alfred Wegener first put forward his ideas of continental drift, but in the first edition of his book Die Ehtstehung der Kontinente und Ozeane there was no specific mention of the Falkland Islands. The first English translation did not appear until 1924, but nonetheless, the idea was adopted by Baker (1924) in his final report on the geological exploration of the islands that he had undertaken. At that time, whilst mainstream European opinion might have been sceptical of Wegener's proposals, it was by no means dismissive. Nonetheless, Baker was very much in the minority in wholeheartedly adopting continental drift as a viable geological process. In the United States of America there was far less tolerance of 'mobilism'. There, after some initial interest, Wegener's suggestion that continents might split apart and move was generally dismissed, although serious opposition did not gather strength until the late 1920s (Newman 1995).

One important champion of the continental drift concept was the South African geologist Alexander du Toit. He, being familiar with the faunal connections, appreciated the importance of the Falkland Islands and, furthermore, saw the mismatch between their geology and their present-day geographical position adjacent to South America. In his reconstructions of Gondwana, du Toit $(1927,1937)$ was the first person to move the islands into a more geologically appropriate position. His solution (Figure 12) was to take the islands north so that they formed a linear link between the comparable geological settings of South Africa's Cape Province and the Ventania region of Argentina. In the fourth edition of his book Wegener (1929) commented approvingly, though stated a preference (unsupported by argument) for the Falklands to lie to the south of Africa rather than to the west. None of this impressed the implacable American opponents of continental drift, amongst whom were most of the leading geologists of the day. Between 1926 and 1928 they had mounted a concerted, coordinated and successful assault on the theory (Newman 1995; Oreskes 1999) which, inevitably, had a negative effect on European opinion. 
With continental drift generally regarded sceptically so things rested, until another South African geologist, Ray Adie, proposed an even more radical solution to the mismatched regional geology of the Falkland Islands. In a remarkably prescient contribution, Adie (1952) used the alignment of structural and sedimentological trends to support his proposal that the Falklands had been rotated by $180^{\circ}$ from an original position adjacent to the east coast of South Africa. This solution to the enigma of Falklands geology was completely neglected until it was 'rediscovered' in terms of microplate rotation (Mitchell et al. 1986) once the plate tectonic revolution had swept through geology. It is now widely accepted in principle. Adie had spent time in the Falkland Islands in 1950 (for a brief biography see Tatham 2008) and a fossil collection that he made at the time is held by the Sedgwick Museum, Cambridge. It is instructive that in his manuscript notes accompanying the fossils, Adie uses the South African stratigraphical term 'Bokkeveld Series' to describe the fossiliferous Falklands beds now known as the Fox Bay Formation. He obviously felt at home.

\section{Epilogue}

The Falkland Islands are in many ways typical of small, remote territories, in that their early, $19^{\text {th }}$ Century geological exploration was a peripheral activity, brief and unplanned, by members of transitory expeditions. Fossil collections made or acquired during those early explorations are now widely distributed amongst different museums, supplemented by subsequent, individual donations of specimens many of which are enigmatic and of uncertain provenance. Not all of the surviving collections have been scientifically described, whilst not all of the described collections have survived. More recent, early $20^{\text {th }}$ Century collections are generally better documented, but their provenance is not invariably secure. Specifically, the Falkland Islands collections are of value from two perspectives. In historical terms, they provide a physical link with the development of scientific theory and methodology, from Charles Darwin to continental drift. In modern terms they provide a readily accessible resource for continuing research on a region to which travel opportunities are still limited. Both of these attributes are enhanced by an awareness of the full extent of the available material, and by an understanding of the different roles played by different 
collections in the evolution of regional geological interpretations. We hope this paper will have contributed to a broader appreciation of these historical fossil collections from the Falkland Islands, now supplemented by material deriving from more recent investigations. These have included academic research based at several UK universities and work by the British Antarctic Survey and the British Geological Survey, the latter acting on behalf of the Falkland Islands Government: see for example Aldiss and Edwards (1999) and Stone et al. (2005). Individual donations of important new finds also continue: see for example Rushton and Stone (2011).

\section{Acknowledgements}

We are grateful for the perceptive comments of Don Aldiss and the two referees, Lyall Anderson and Patrick Wyse-Jackson, which have much improved this paper. For assistance in locating material we thank the following: Sarah Long, Peter Tandy Claire Mellish and Peta Hayes, The Natural History Museum, London; Suzanne Miller and Lyall Anderson, National Museums Scotland, Edinburgh - (SM is now at the Museum of South Australia, Adelaide, LA is now at the Sedgwick Museum, Cambridge); Matt Riley, Sedgwick Museum, University of Cambridge; Lesley Appleton, Imperial College, London; John Faithful, Hunterian Museum, University of Glasgow; the late Jane Cameron, Falkland Islands Government Archive, Stanley. The NHM specimens illustrated were photographed by Phil Crabb. PS acknowledges the support of the Department of Mineral Resources, Falkland Islands Government, and contributes by permission of the Executive Director, British Geological Survey (NERC).

\section{References}

Adie, R. J. 1952. The position of the Falkland Islands in a reconstruction of Gondwanaland. Geological Magazine, 89, 401-410.

Aldiss, D. T. and Edwards, E. J. 1999. The Geology of the Falkland Islands. British Geological Survey Technical Report WC/99/10. 136 pp.

Anderson, L. I. 2009. The Sedgwick Museum: Darwin's geological specimens. In: Pearn, A. M. (ed.) A Voyage Round the World - Charles Darwin and the Beagle collections in the University of Cambridge. Cambridge University Press. 68-71: 
Andersson, J. G. 1907. Contributions to the geology of the Falkland Islands. Wissenschaftliche Ergebnisse der Schwedischen Sudpolar-expedition 1901-1903, 3 (Lief. 2), 38 pp.

Armstrong, P. 1992. Darwin's Desolote Islands: a Naturalist in the Falklands, 1833 and 1834. Picton Publishing, Chippenham. 147 pp.

Baker, H. A. 1924. Final Report on Geological Investigations in the Falkland Islands, 1920-1922. Government Printer, Stanley.

Carvalho, M. Da G. P. de, 2006. Devonian trilobites from the Falkland Islands. Palaeontology, 49, 21-34.

Clarke, J. M. 1913a. Fósseis Devonianos do Paraná. Monographia do Serviço Geológico y Mineralógico do Brasil, No 1, 353 pp, 27 plates.

Clarke, J. M. 1913b. Illustrations of the Devonic fossils of southern Brazil and the Falkland Islands. New York State Museum Bulletin, 164, 140-209.

Clarke, J. M. 1919. The death of Lady Allardyce. Science, 50, 585.

Cleevely, R. J. 1983. World Palaeontological Collections. London, British Museum (Natural History), Mansell Publishing Ltd.

Darwin, C. 1839 (revised editions 1845 \& 1860). Journal of Researches into the Geology and Natural History of the Various Countries visited by H.M.S. Beagle. Henry Colburn (1839), Ward, Lock and Bowden (1845 \& 1860). 492 pp.

Darwin, C. R. 1846. On the geology of the Falkland Islands. Quarterly Journal of the Geological Society of London, Vol. 2, 267-274.

Darwin Correspondence Project Database, Letters 730 and 886, http://www.darwinproject.ac.uk.

Du Toit, A. L. 1927. A geological comparison of South America with South Africa. Carnegie Institution, Washington.

Du Toit, A. L. 1937. Our Wandering Continents. Oliver \& Boyd, Edinburgh \& London, 366 pp.

Edgecombe, G. D. 1994. Calmoniid trilobites from the Devonian Fox Bay Formation, Falkland Islands: systematics and biogeography. New York State Museum Bulletin, Vol. 481, 55-68.

Etheridge, R. 1885. Notes on the fossils collected by the Expedition. Report on the scientific results of the voyage of H.M.S. Challenger during the years 1873-76. Narrative - Vol. 1 (2 ${ }^{\text {nd }}$ Part), 892-894.

Fuchs, V. 1982. Of Ice and Men. Anthony Nelson, Oswestry. 383 pp. 
Greenway, M. E. 1972. The geology of the Falkland Islands. British Antarctic Survey Scientific Reports, 76, 42 pp.

Halle, T. G. 1912. On the geological structure and history of the Falkland Islands. Bulletin of the Geological Institution of the University of Uppsala, 11, 115-229.

Herbert, S. 2005. Charles Darwin, Geologist. Ithaca and London, Cornell University Press. 485 pp.

Keynes, R. D. (editor) 1988. Charles Darwin’s Beagle Diary. Cambridge University Press. 464 pp.

Macphail, M. \& Cantrill, D. J. 2006. Age and implications of the Forest Bed, Falkland Islands, southwest Atlantic Ocean: evidence from fossil pollen and spores.

Palaeogeography, Palaeoclimatology, Palaeoecology, 240, 602-629.

Maisey, J. G., Borghi, L. \& Carvalho, M. Da G. P. de. 2002. Lower Devonian fish remains from the Falkland Islands. Journal of Vertebrate Paleontology, 22, 708-711.

Mitchell, C., Taylor, G. K., Cox, K. G. \& Shaw, J. 1986. Are the Falkland Islands a rotated microplate? Nature, 319, 131-134.

Morris, J. and Sharpe, D. 1846. Description of eight species of brachiopodous shells from the Palaeozoic rocks of the Falkland Islands. Quarterly Journal of the Geological Society of London, Vol. 2, 274-278.

Newman, R. P. 1995. American Intransigence: The Rejection of Continental Drift in the Great Debates of the 1920s. Earth Sciences History, Vol. 14, 62-83.

Newton, E. T. 1906. Notes on fossils from the Falkland Islands brought home by the Scottish National Antarctic Expedition in 1904. Proceedings of the Royal Physical Society of Edinburgh, Vol. 16, 248-257.

Nordenskjöld, O. \& Andersson, J.G. 1905. Antarctica. London, Hurst \& Blackett Ltd.

Oreskes, N. 1999. The Rejection of Continental Drift. Oxford University Press, New York and Oxford, xi + 420 pp.

Pernety, Dom A. J. 1771. The history of a voyage to the Malouine (or Falkland) Islands, under the conmmand of $M$ de Bougainville, in order to form a settlement there. Translated from the French of Dom Pernety's Historical Journal (1770) and printed in London for T. Jefferys.

Richter, R. and Richter, E. 1942. Die Trilobiten der Weismes-Schichten am Hohen Venn, mit Bemerkungen über die Malvinocaffrische Provinz. Senckenbergiana [Senckenbergischen Naturforschenden Gesellschaft], Vol. 25, 156-179.

Ross, J. C. 1847. A voyage of discovery and research in southern and Antarctic regions, during the years 1839-43. Vol 2. John Murray, London. 447 pp. 
Rushton, A. W. A \& Stone, P. 2011. Two notable fossil finds in East Falkland: a 'starfish' and a large trilobite. The Falkland Islands Journal, Vol. 9 (5), 5-13.

Seward, A. C. \& Walton, J. 1923. On a collection of fossil plants from the Falkland Islands. Quarterly Journal of the Geological Society, London, 79, 313-333.

Sharpe, D. \& Salter, J. W. 1856. Description of Palaeozoic fossils from South Africa. Transactions of the Geological Society of London, Series 2, Vol. 7, 203-225.

Stone, P. 2009. Mrs Allardyce and the trilobite. The Falkland Islands Journal, 9 (3), 9-16.

Stone, P., Aldiss, D. T. and Edwards, E. J. 2005. Rocks and fossils of the Falkland Islands. British Geological Survey for Department of Mineral Resources, Falkland Islands Government. 60 pp.

Stone, P. and Rushton, A. W. A. 2006. The Baker Collection of Falkland Island fossils at Imperial College, London. The Falkland Islands Journal. 8 (5), 17-22.

Stone, P. \& Rushton, A. W. A. 2007. Fossil collections from the Falkland Islands: the Beagle, Erebus \& Terror, Challenger and Scotia expeditions. The Falkland Islands Journal, 9 (1), 124-133.

Tatham, D. (ed.) 2008. The Dictionary of Falklands Biography. Published by the editor, Ledbury, Hereford.

Thomson, C. W. 1877. The voyage of the Challenger, Vol. 2 - The Atlantic. MacMillan and Co., London. 396 pp.

Trewin, N. H. 2000. The ichnogenus Undichna, with examples from the Permian of the Falkland Islands. Palaeontology, 43, 979-997.

Weddell, J. 1825. A voyage towards the South Pole performed in the years 1822-24. Second edition (1827) reprinted 1970, David \& Charles, Newton Abbot, 324 pp.

Wegener, A. 1929. Die Ehtstehung der Kontinente und Ozeane (4th edition). Friedrich Vieweg \& Sohn, Braunschweig. English translations as The Origin of Continents and Oceans were published in the USA by Dover Publications Inc. (1966) and in the UK by Methuen \& Co., London (1967).

Woodward, A. S. 1904. The Department of Geology. In: The History of the collections contained in the Natural History Departments of the British Museum, 1, Library and Departments of Botany, Geology and Minerals. London, Trustees of the British Museum. 


\section{Figure Captions}

1. The Falkland Islands showing the outline geology and the outcrop of the Fox Bay Formation together with the position of localities mentioned in the text.

2. A specimen collected by Charles Darwin at Port Louis, East Falkland. The brachiopods Australospirifer hawkinsii (labelled b) and Schellwienella sulivani (labelled c and named after Lieutenant Bartholomew Sulivan of HMS Beagle) are associated with a scattering of crinoid columnals. The Falkland Islands 2 pence coin is $25 \mathrm{~mm}$ in diameter. (C) The Natural History Museum, London (B17794).

3. (a) A specimen of laminated, fine-grained sandstone with impressions of the brachiopod Australocoelia palmata collected at Burnt Harbour on Saunders Island, West Falkland, by Bartholomew Sulivan in 1844/45 and subsequently passed on to Charles Darwin. (b) The locality name has been scratched on the reverse side of the specimen, presumably by Sulivan. The Falkland Islands 2 pence coin is $25 \mathrm{~mm}$ in diameter. The Natural History Museum, London (B17821).

4. A specimen from the Falkland Islands featuring examples of the brachiopod Australospirifer hawkinsii, presented to the NHM by Robert Etheridge Senior in 1869. The Falkland Islands 2 pence coin is $25 \mathrm{~mm}$ in diameter. Linear scale in $\mathrm{mm}$. (C) The Natural History Museum, London (BB17520).

5. Falkland Islands specimens of the brachiopod Australocoelia palmata from the Sharpe Collection, together with the accompanying manuscript note acknowledging C. Darwin Esq. The Falkland Islands 5 pence coin is $17 \mathrm{~mm}$ in diameter. (C) The Natural History Museum, London (B56252-54).

6. A fossil specimen from the McCormick Bequest, collected during the Erebus \& Terror Expedition at Port Salvador, East Falkland. The brachiopod Notiochonetes skottsbergi (Clarke); internal moulds of a large ventral valve (below) and dorsal valves (centre and right) are associated with traces of tentaculitids and crinoid columnals. Linear scale in $\mathrm{cm}$ and mm.C The Natural History Museum, London (BB19004). 
7. A fossil specimen brought back by the Scotia Expedition from Port Louis, East Falkland. Internal moulds of the brachiopod Australocoelia palmata (Morris \& Sharpe), showing ventral valve (12) and dorsal valve (13). The Falkland Islands 5 pence coin is $17 \mathrm{~mm}$ in diameter. BGS photograph number P599488. The specimen is in the collections of the National Museums Scotland (NMS.G.1854.3.45).

8. A cephalon of the calmoniid trilobite Bainella nilesi? Collected from Pebble Island and prepared by the authors (PS and AWAR respectively) and now in the NHM collection. The fine detail of the fossil, including the individual lenses of the compound eye, has been preserved in a carbonate-rich concretion: a. plan view, b. side view. Linear scale in mm. CNatural History Museum, London (It27132).

9. A specimen of wood from the West Point Island "buried forest" presented by Governor Allardyce to The Natural History Museum, London, in 1909. Linear scale in mm. CNatural History Museum, London (V.11489).

10. A pygidium of the homalonitid trilobite Burmeisteria herschelii collected by H. A. Baker from Pebble Island and presented to the NHM in 1931. Linear scale in $\mathrm{cm}$ and $\mathrm{mm}$. CNatural History Museum, London (In28179).

11. A cephalon of the homalonitid trilobite Burmeisteria herschelii collected on Pebble Island by members of the 1934-37 British Graham Land Expedition, passed on to Arthur Bennett and presented to the NHM in 1956. Linear scale in cm and mm. CNatural History Museum, London (In34989).

12. Part of Alexander du Toit's pre-drift reconstruction of the South Atlantic region, as published in his 1937 book 'Our Wandering Continents' (Figure 13), showing the Falkland Islands repositioned farther north to provide a linear geological link between South Africa and South America. 
West Point Island

WEST FALKLAND
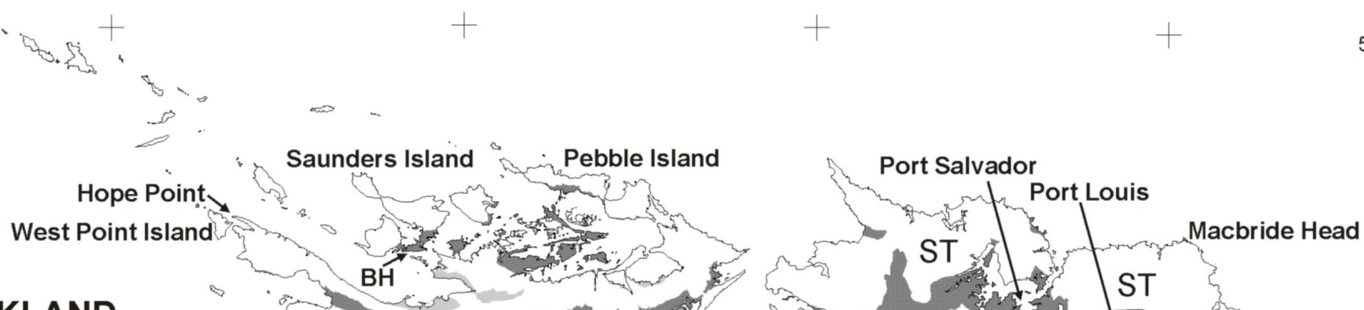
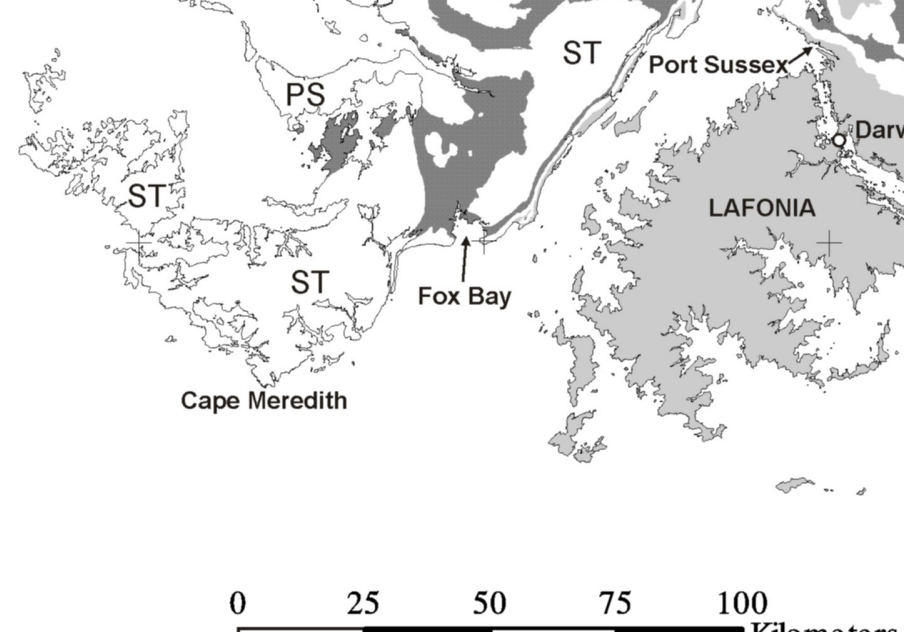

Kilome ters

Burnt Harbour

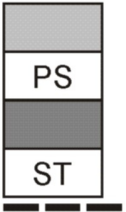

\section{Lafonia Group: Carboniferous - Permian}

Port Philomel and Port Stanley Formations: Devonian - ?Carboniferous

Fox Bay Formation: Devonian

Port Stephens Formation: ?Silurian - Devonian

Cape Meredith Complex: Precambrian 


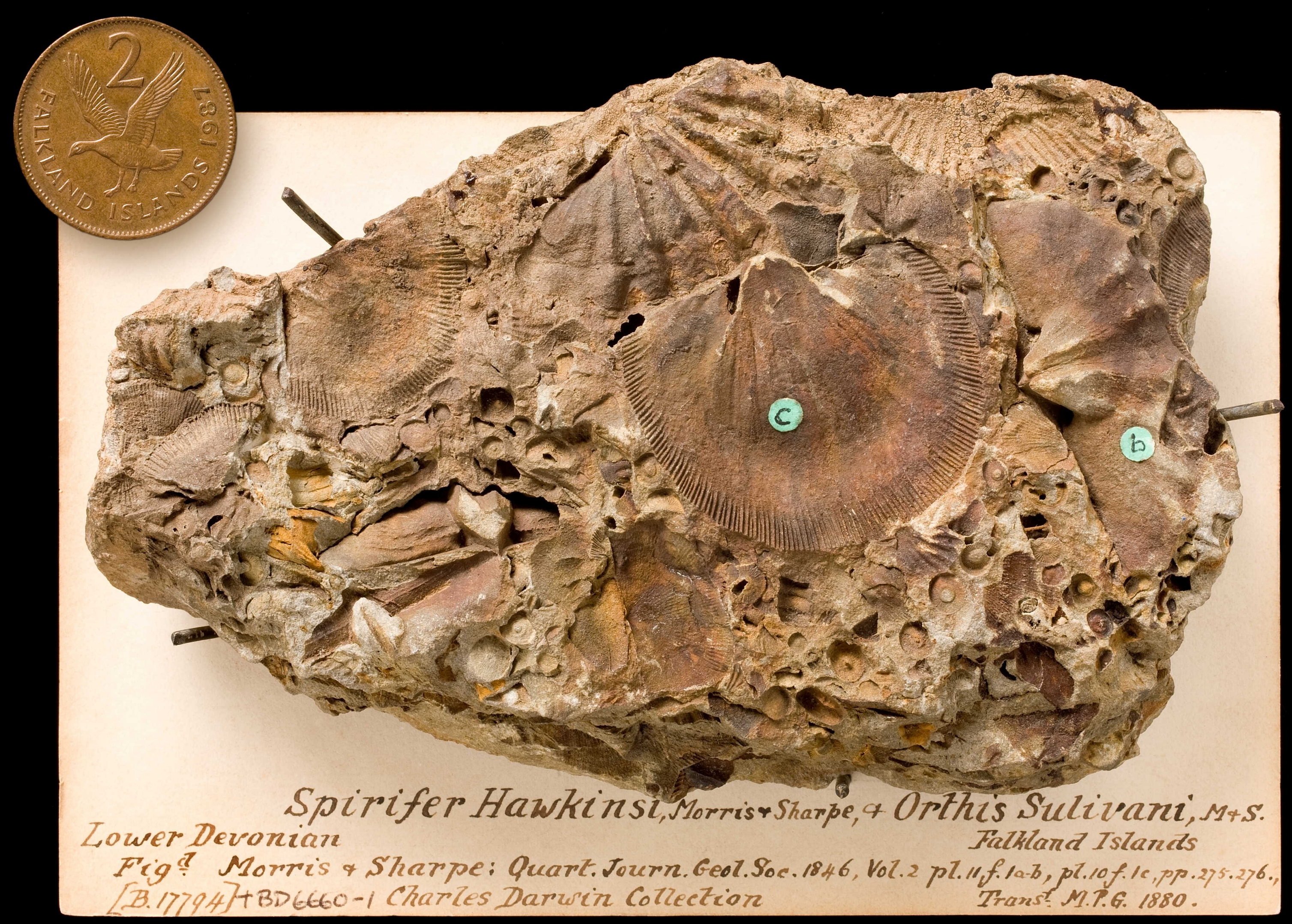



(1)

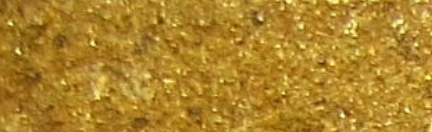

\section{s:

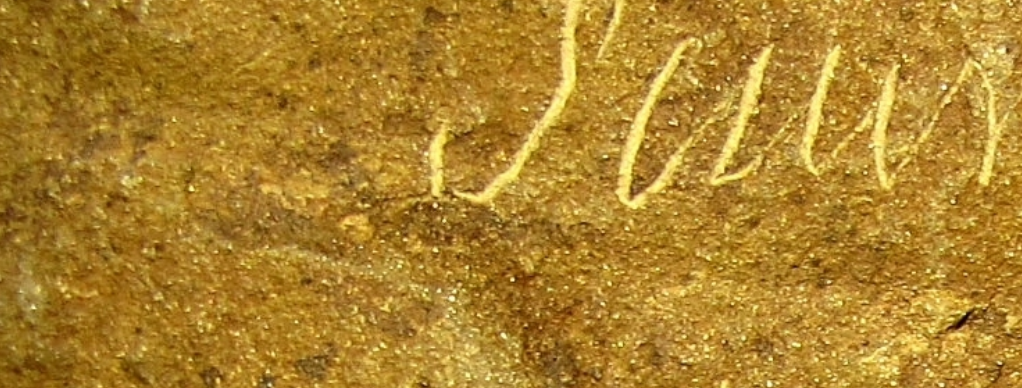

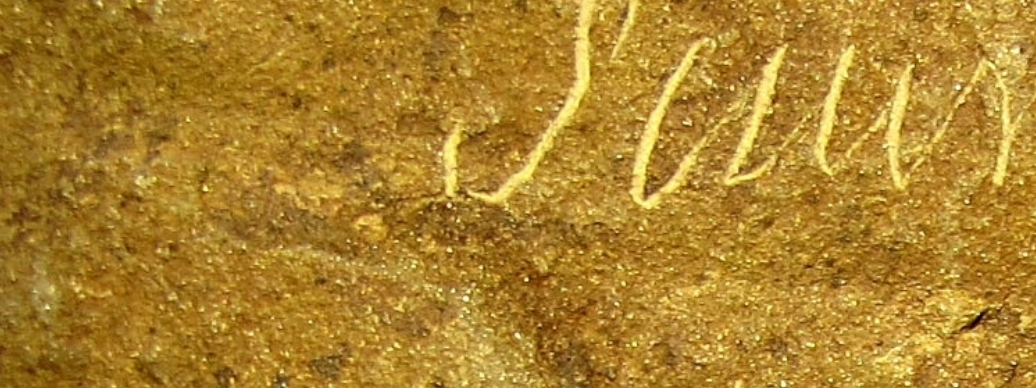

$x^{2}+\frac{2}{2}$

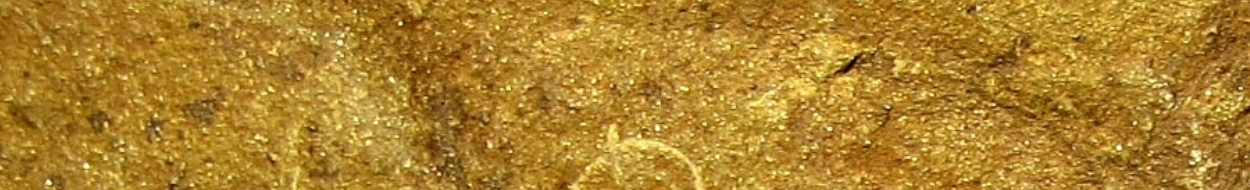

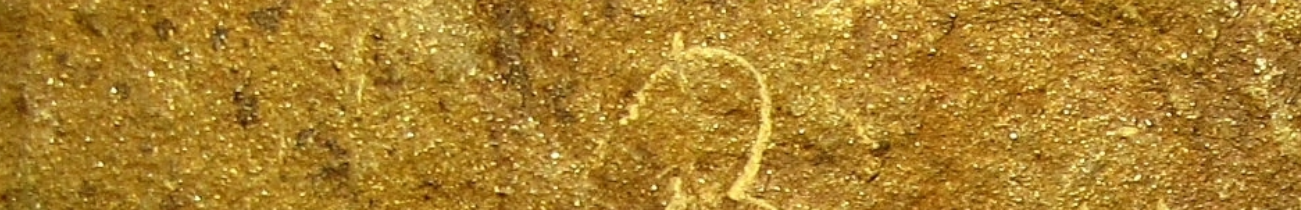

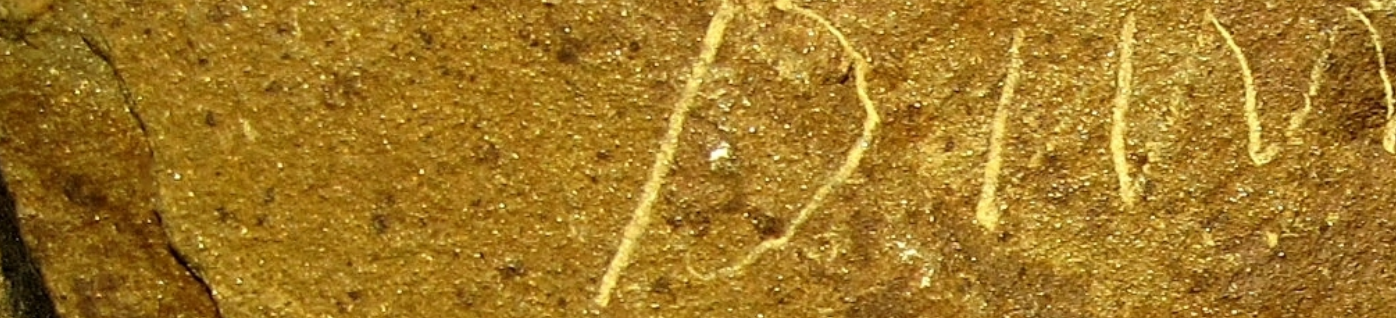

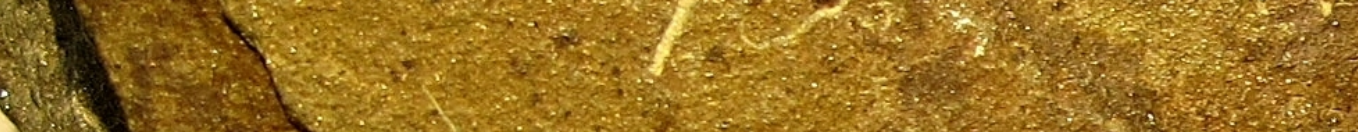

$(1+2)$

H.

$\sqrt{\frac{2}{2}}$

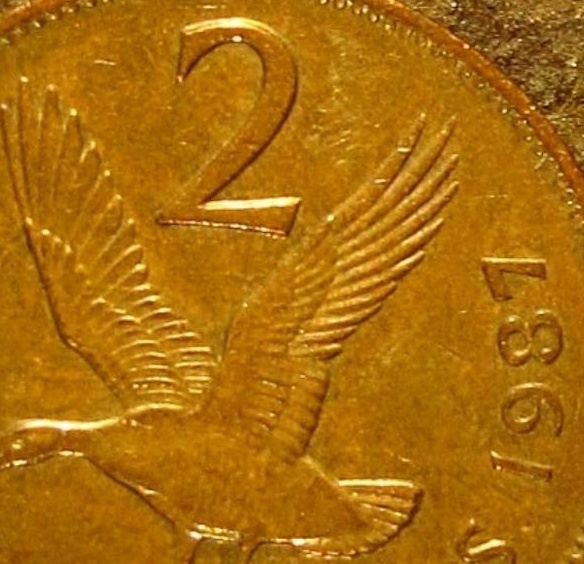

(1)

319821

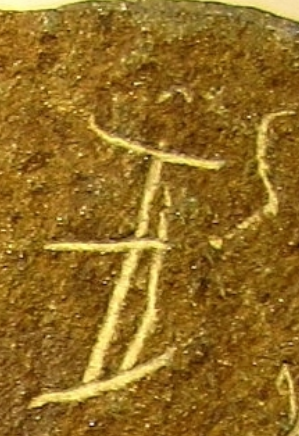

y
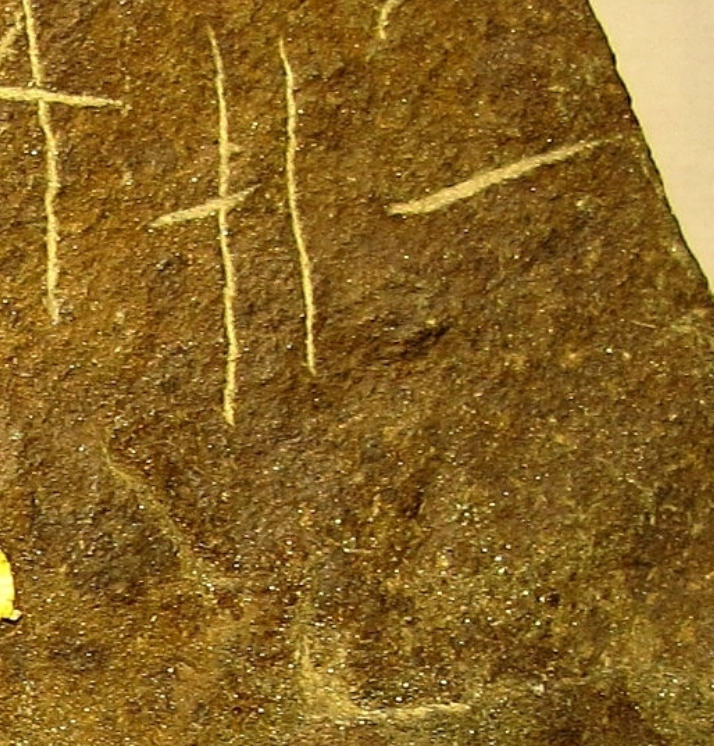

3.

4. 


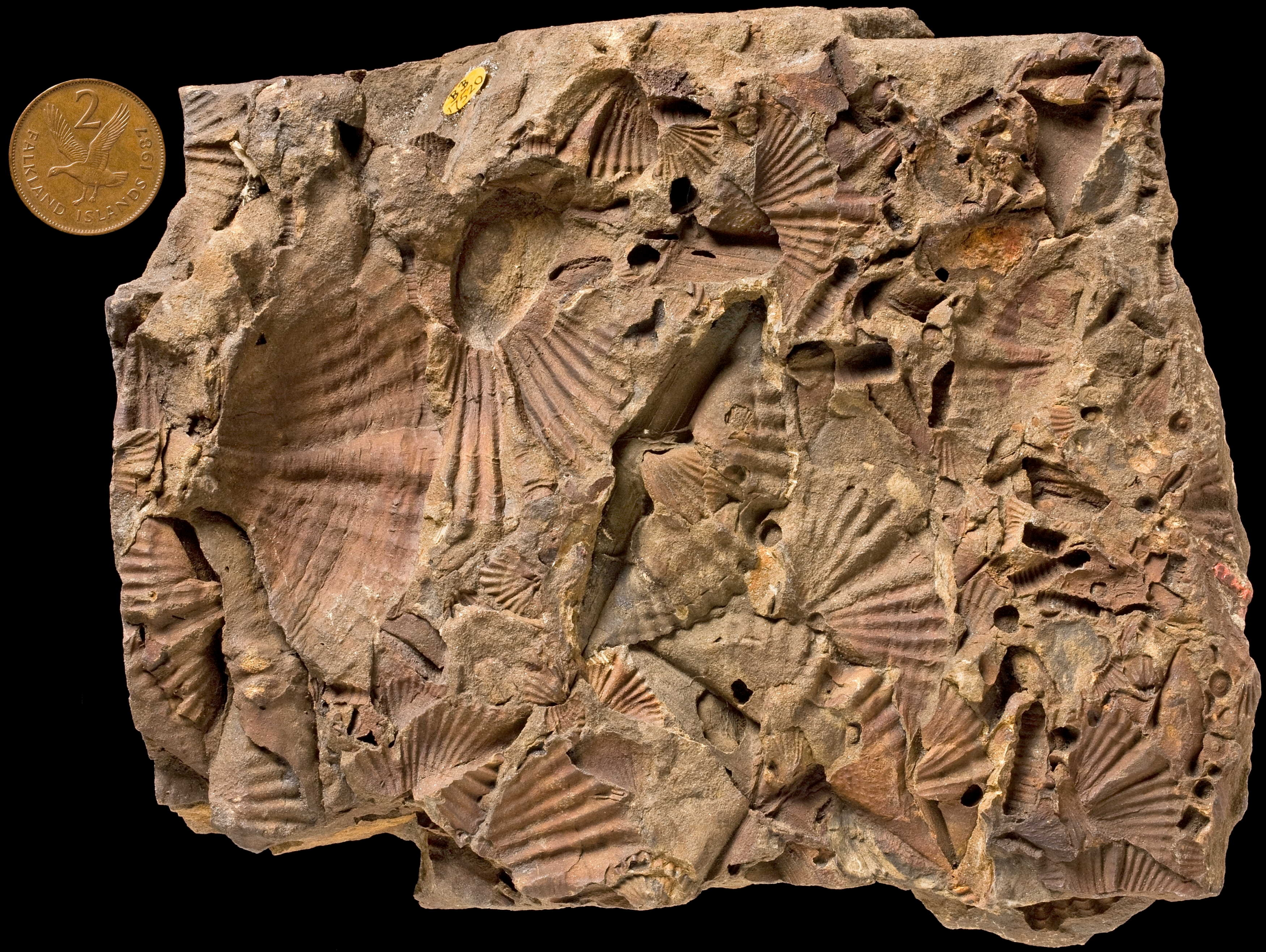

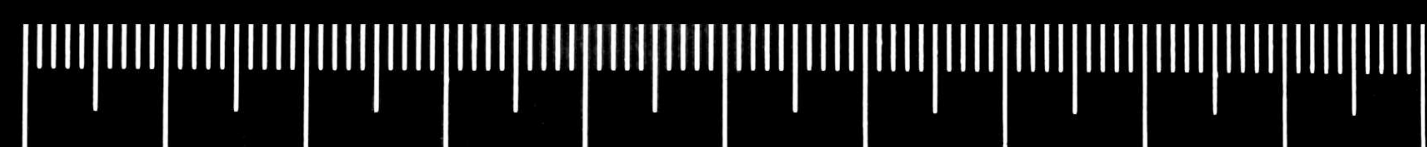





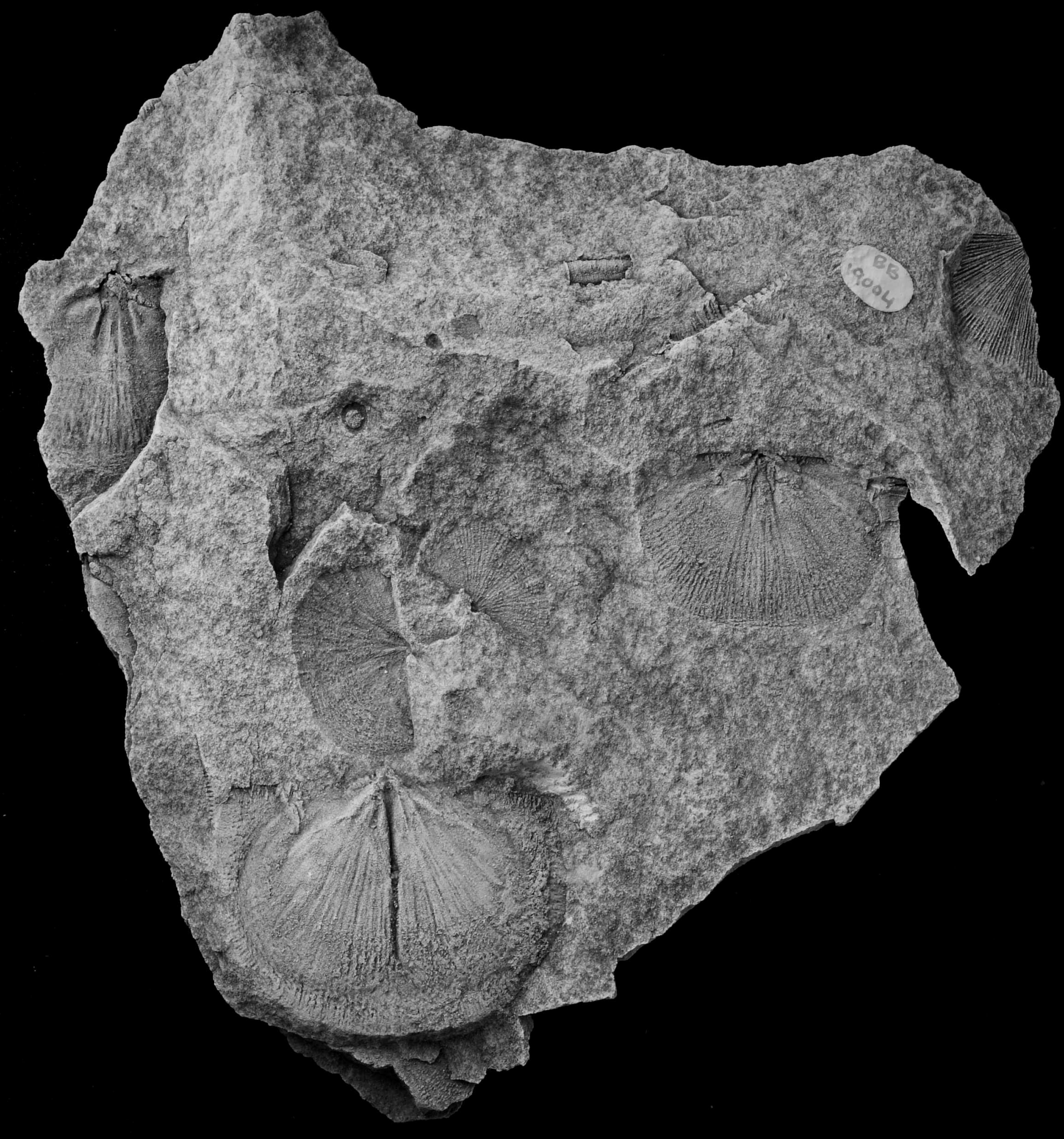

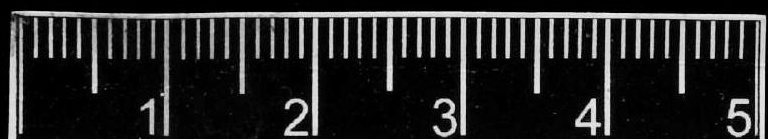




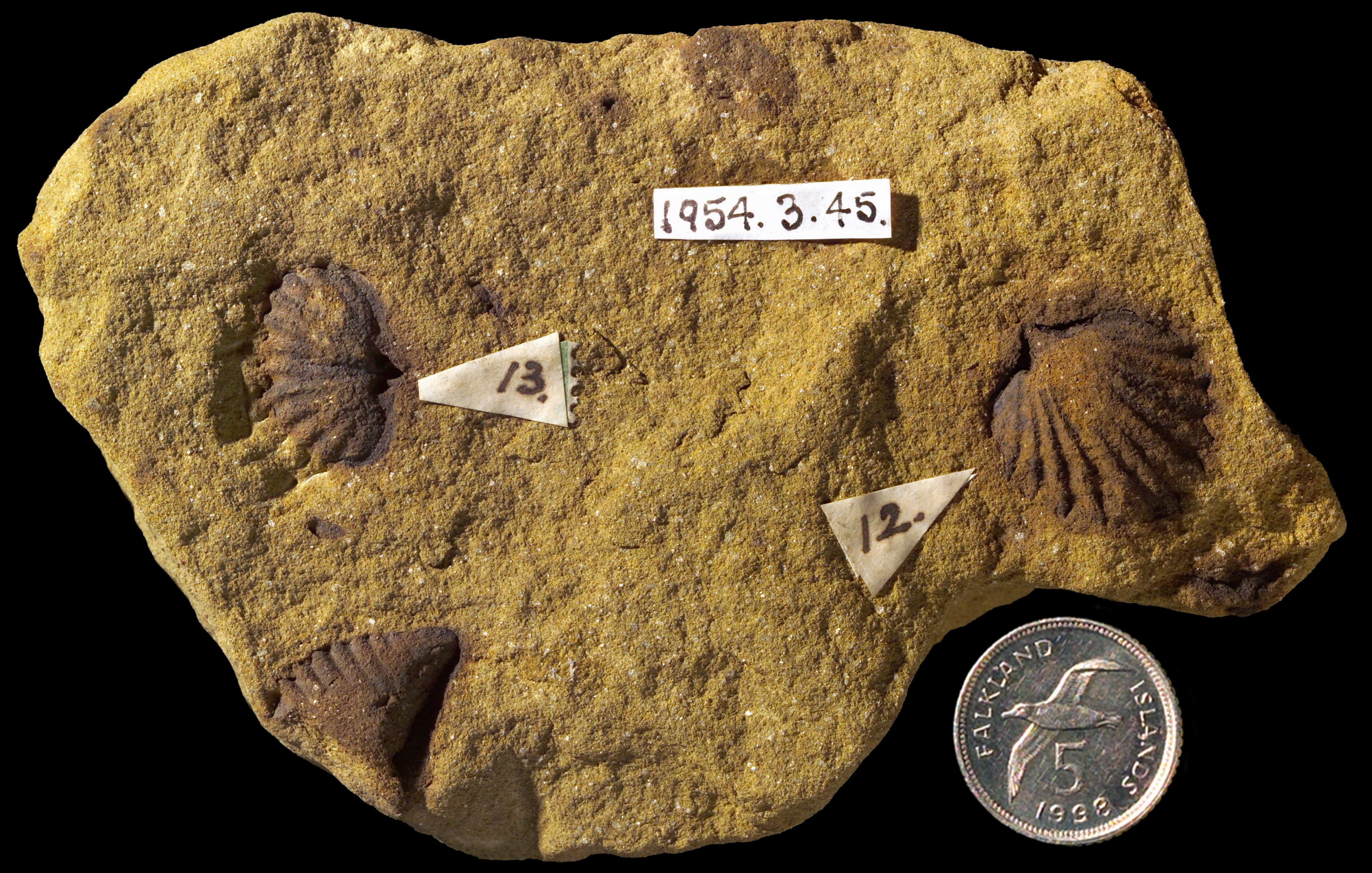

$5 \mathrm{~cm}$ 


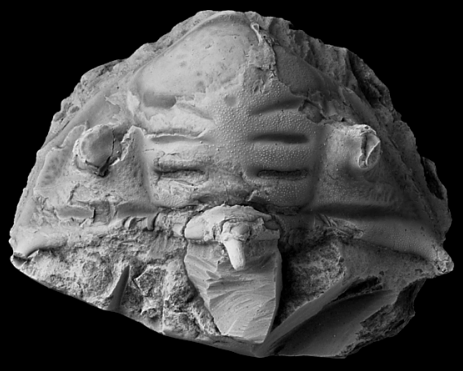

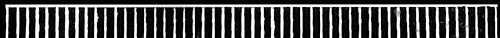




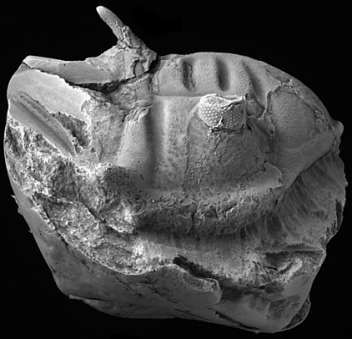




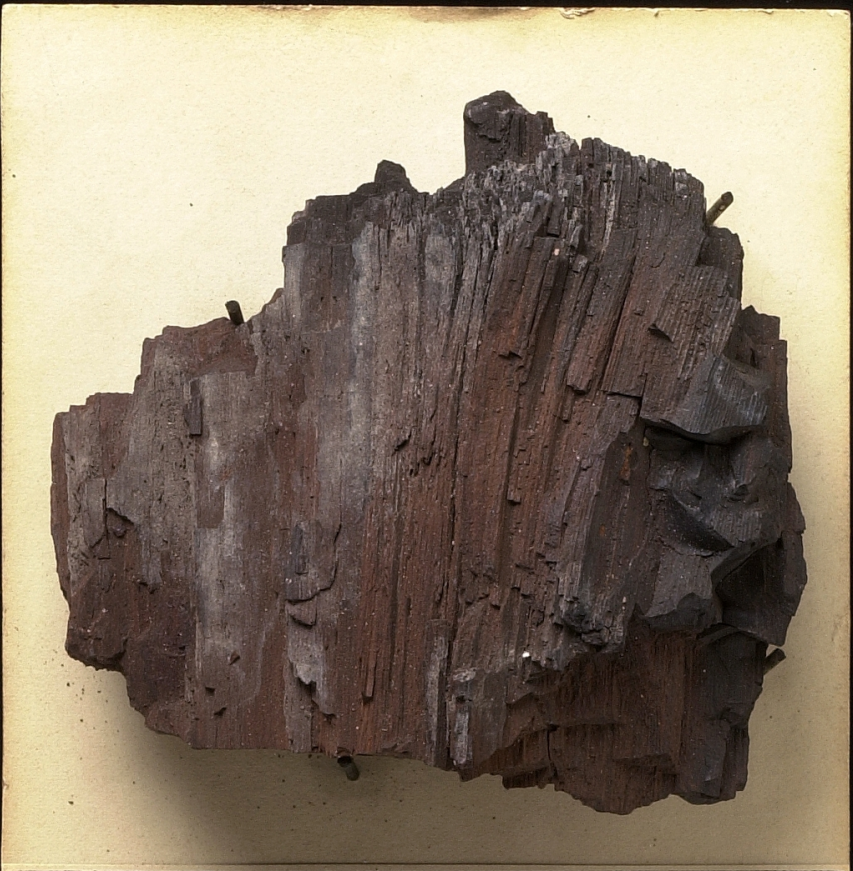

\section{FOSSIL WOOD}

from West Point Island, FaLkLand IsLands, supposed to indicate the former presence of forests in that now treeless land,

[V. 11489] Presented by His Excellency W. L. Allardyce, C.M.G., 1909. 

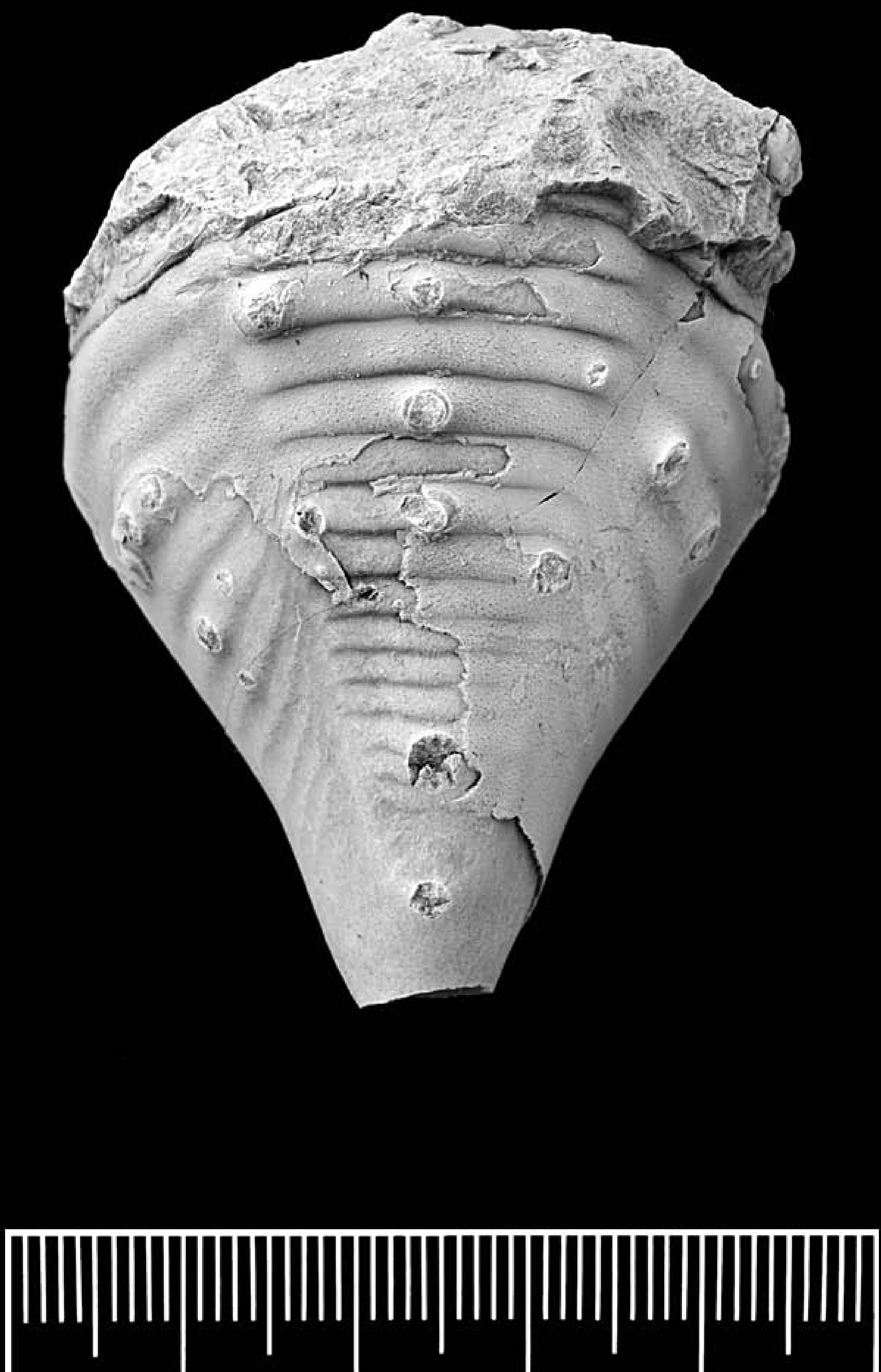


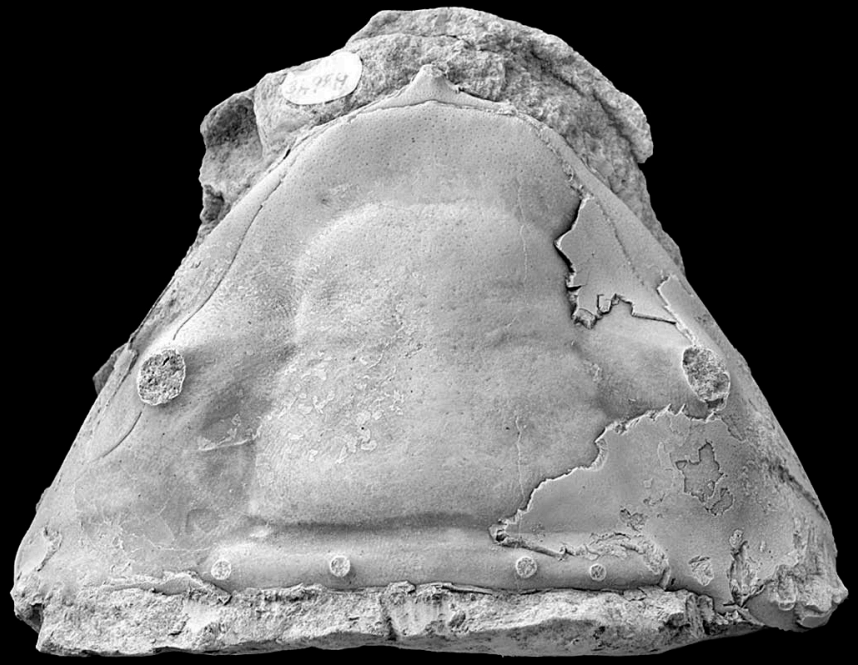

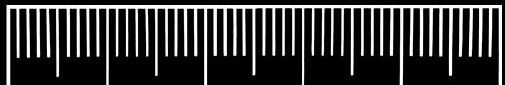


